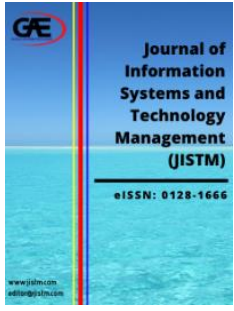

\author{
JOURNAL OF INFORMATION \\ SYSTEM AND TECHNOLOGY \\ MANAGEMENT (JISTM)

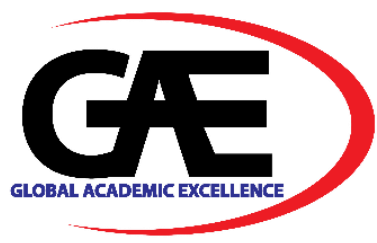

\title{
AN OVERVIEW OF AGENT-BASED MODELLING APPROACHES FOR INTEGRATED FLOOD MANAGEMENT
}

\author{
Ling Sie Chiew ${ }^{1 *}$, Shahabuddin Amerudin ${ }^{2}$, Zainab Mohamed Yusof ${ }^{3}$ \\ 1 Faculty of Built Environment and Surveying, Universiti Teknologi Malaysia, Malaysia \\ Email: chiew1992@graduate.utm.my \\ 2 Faculty of Built Environment and Surveying, Universiti Teknologi Malaysia, Malaysia \\ Email: shahabuddin@utm.my \\ 3 School of Civil Engineering, Faculty of Engineering, Universiti Teknologi Malaysia, Malaysia \\ Email: zainabyusof@utm.my \\ * Corresponding Author
}

\section{Article Info: \\ Article history: \\ Received date: 01.10 .2021 \\ Revised date: 01.11 .2021 \\ Accepted date: 20.11 .2021 \\ Published date: 01.12.2021 \\ To cite this document: \\ Chiew, L. S., Amerudin, S., \& Mohamed Yusof, Z. (2021). An Overview of Agent-Based Modelling Approaches for Integrated Flood Management. Journal of Information System and Technology Management, 6 (24), 290-300.}

DOI: $10.35631 / J I S T M .624027$

This work is licensed under $\underline{\text { CC BY } 4.0}$ (a)

\begin{abstract}
:
Previously, Integrated Flood Management (IFM) system has been implemented by several hydrological researchers in order to minimize the global flood risk by providing a convincing flood risk assessment and management, as well as sustainable adaptation and disaster alleviation policy. Flood risk is dynamic interaction between natural disasters and human vulnerability. Basically, methods for quantifying flood risk are fully-fledged but tend to treat artificial and economic vulnerabilities as static or subject to changes in external trends. However, interpretive research is rarely conducted to investigate people's decision-making and acknowledge to flood warnings during flood event. The integration of Agent-Based Model (ABM) in simulating the interactions and dynamic responses of individual or organizations in a spatial environment during the flood events or prior to the events were reviewed. The ABM model is defined as a computational method used to simulate the behaviour and the interaction of autonomous decisionmaking entities in a network or system it is used to evaluate their impact on the entire system. Therefore, the ABM approach has been chosen to emulate the complexity of the IFM process due to its capability and flexibility to simulate the dynamic of human-environment scenarios in the spatial environment.
\end{abstract}

Keywords:

Integrated Flood Management, Agent-Based Modelling, Disaster Management 


\section{Introduction}

Over the past two decades, flooding has been one of the most ordinary weather-related natural disasters (47\%), and it has influenced 2.3 billion people worldwide (CRED-UNISDR, 2015). According to Rentschler and Salhab (2020), they estimated that more than 2.2 billion people, or $29 \%$ of the world's population, live in areas that will be submerged to a certain extent in a 100 -year flood event. Approximately 1.47 billion people, or $19 \%$ of the world's population, were directly exposed to a submersion depth of more than 0.15 meters, which will pose a major threat to life, especially the lives of vulnerable people (1.36 billion people) in East and South Asia.

Generally, flood events lead to undesirable consequences and affect communities, infrastructure, environment, and individuals according to the severity of the flood event itself. Therefore, various hydrological researchers have implemented Integrated Flood Management (IFM), such as providing convincing flood risk assessment and management, and sustainable adaptation and disaster alleviation policy to minimize global flood risk (Bubeck et al., 2017; Qi et al., 2019; Fu et al., 2020; Jamali et al., 2020). This is because the flood is the dynamic interaction between natural disasters and human vulnerability.

The Department of Irrigation and Drainage (DID) has responsible for flood management in Malaysia. Recent IFM flood management plan, the DID has improved the function of the river basin and utilize the benefits of flood control system by adopted the Integrated River Basin Development and the IFM methods in its flood management plan (See et al., 2017). However, as an engineering-based organization, DID's approach mainly focuses on structural measurement for control floods and lacks an overall approach to flood management. The interpretive research is rarely conducted to investigate people's decision-making for flood warnings during or prior the flood event. Therefore, the integration of Agent-Based Model $(\mathrm{ABM})$ in simulating the interactions and dynamic responses of individual or organizations in a spatial environment were reviewed in this paper.

\section{Integrated Flood Management (IFM)}

Recently, traditional flood management method has had a positive impact on flood reduction. However, the traditional methods have also brought many deficiencies such as based on structural measures, planned in a mono-disciplinary manner, lacking climate change adaption and mitigation measures which only focusing on negative aspects of flooding and reduction of flood damage. Therefore, it is generally recognized that it is necessary to shift from flood control paradigm to flood management and to prevent, manage flood risk and coexist with flood concurrently. In the past, various hydrological researchers have implemented IFM, such as providing convincing flood risk assessment and management to minimize global flood risk (Albano et al., 2017; Klijn et al., 2015; Morrison et al., 2018; Vercruysse et al., 2019).

According to Qiu (2017), IFM is determined as a new method that can enthusiastic the watershed resources operation, maintain and increase the floodplains productivity and provide protective measures to prevent losses caused by floods. In general, IFM is a concept that solves human security and sustainable development issues from the perspective of flood management within the framework of Integrated Water Resources Management (IWRM). It also essentials a comprehension of the social vulnerability of flood disasters, the flood risk configuration, and society's cogitation of these risks (Jamali et al., 2020). 
In Suriya and Mudgal (2013), IFM is a subset of IWRM, which aims to maximize the net benefits of floods, such as replenishing water resources, restoring river ecosystems, and minimizing the loss of life caused by floods. In IFM management, the understanding of the vulnerability of society to flood disasters and society's perception of these risks can be determined by emphasizing different aspects of flooding, coordination, and stakeholder participation in a broad perspective of flood management. Figure 1 shows that conceptual framework of IFM approach.

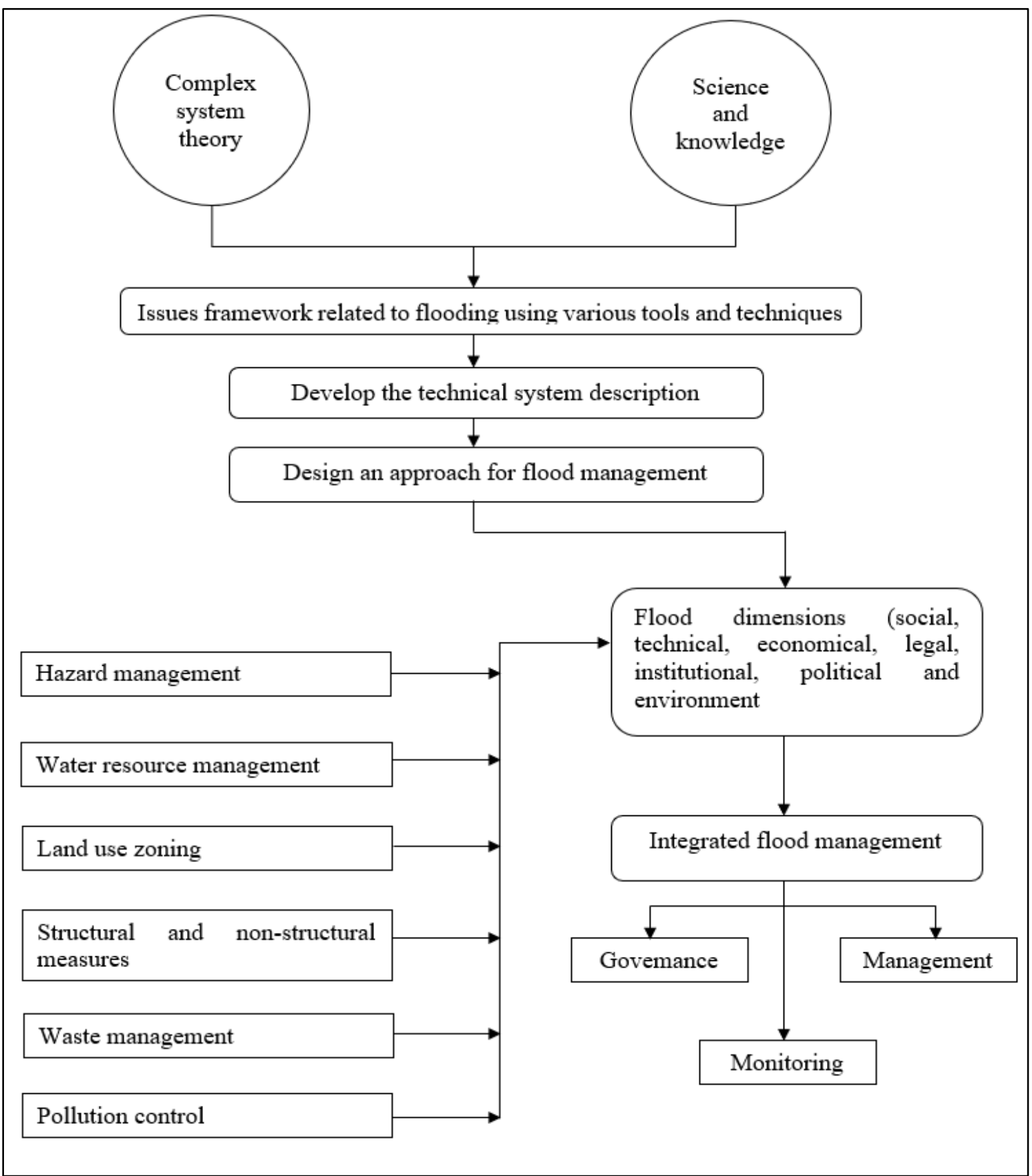

Figure 1: The conceptual framework of IFM Approach

Source: Suriya and Mudgal, 2013 


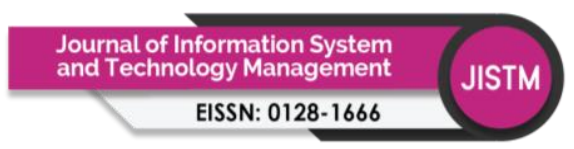

Volume 6 Issue 24 (December 2021) PP. 290-300 DOI: 10.35631/JISTM.624027

IFM management plan addresses five key elements of flood management that seem to logically follow in the context of the IWRM approach, such as the water cycle management, the integration of land and water resources management, integrates a combination of strategies, ensure of a participatory approach and hazard management methods (Jamali et al., 2020). IFM also addresses issues related to human safety and sustainable development from the perspective of flood management. For example, it also addresses the vulnerability and risk of floods through preventive measures, while protecting the ecosystem and its associated biodiversity (Halbe et al., 2018; Waghwala and Agnihotri, 2019). Therefore, while recognizing that the changes in the interaction between water and the land environment have produced gains and losses, IFM it is necessary to balance development requirements and flood losses to improve the function of the entire basin.

\section{ABM Definition and Features}

$\mathrm{ABM}$ is well known as a modelling approach that can indicate the transform from social science to the use of models that work on an individual level (Railsback and Grimm, 2019). It is also defined as a computing approach that includes several elements such as appearance, evolutionary programming, theories of game, computational sociology, the complexity of the system, and multi-agents' system (Helbing, 2012).

According to Singh (2016), ABM refers to a computing model that involves dynamic intentions, responses, and intercommunication convention among agents in a shared environment to determine its devise and capability and gain perceptions into its emerging conduct and attributes. Therefore, the ABM model has been used to simulate the reality with a set of self-managing agents, which can be used as simple entities in the calculation code segment, or as intelligent objects.

In addition, the ABM model is also defined as a social system modelling method which is composed of interacting and interacting agents that can learn from their experience and adapt to their behaviour to be more suitable for the environment (Macal, 2020). Each agent can evaluate its condition and make decisions based on a set of regulations independently. In general, the ABM model framework can be categorized into two parts, such as the behaviour of the agent and the physical environment of the model (Rebaudo et al., 2011).

In the ABM model, an agent is defined as an entity that contains a set of beliefs, expectations, and intentions to simulate the behaviour and performance of the system in real situations (Helbing, 2012; DeAngelis and Diaz, 2019). The required agent information can be specified according to the data structure, the mechanism of operating information, and the rules of interaction with each other and with the environment, thereby defining agents into different categories (Bandini, 2020). The ABM environments refer as the space in which the agent conducts behaviour and interaction either it may in discrete, continuous or network based. By using designated software, modelers can set the commands to control the agent's movement or path in a particular environment and their interactions with each other (Castiglione, 2020).

Previously, ABM model has been used to understand the complexity of human environmental systems, such as urban planning (Alghais and Pullar, 2018), criminology (Groff et al., 2019; Chiew \& Amerudin, 2019), education (Harland and Heppenstall, 2012; Chiew \& Amerudin, 
2020), biological model infectious diseases (Chen et al., 2019) and political stability and identity (Fagiolo and Roventini, 2012). ABM model as a computational modelling also has been used to understand how human decisions and behaviours leading to flooding disaster from several aspects or dimensions.

\section{Review The Challenges of Applying the ABM Model in Flood Management}

Flood disaster is defined as a Complex Human and Natural System (CHANS), which requires a process-based approach to understand the complexity relationship of human decision-making towards the flood events. According to Tesfatsion (2017), the ABM model has advantages in emulating human decision-making processes and behaviours by combining them with the context of the social environment, especially in understanding the human flood system.

Although ABM model is still in its infancy in flood risk management research, it seems to have begun to arouse more interest in the man-made part of the flood system (Coates et al., 2019). For instance, several researchers have developed ABM models to study the effectiveness of physical/structural and social disaster prevention and adaptation measures to reduce the impact of major floods and recover (Coates et al., 2019; Dawson et al., 2011; Klijn et al., 2015; Turrell, 2016). Table 1 shows the review of recent studies for the application of the ABM model in IFM management.

Table 1: A Review of Simulation of ABM Model in IFM Management

\begin{tabular}{|c|c|c|c|c|c|c|c|c|}
\hline $\begin{array}{l}\text { Author } \\
\text { (Year) }\end{array}$ & $\begin{array}{c}\text { Coupled } \\
\text { model }\end{array}$ & Agent & $\begin{array}{l}\text { Flood } \\
\text { type }\end{array}$ & Calibration & Validation & $\begin{array}{l}\text { Main } \\
\text { output }\end{array}$ & Scale & $\begin{array}{l}\text { Future } \\
\text { scenario }\end{array}$ \\
\hline $\begin{array}{l}\text { Michaelis et } \\
\text { al. (2020) }\end{array}$ & LisFlood & $\begin{array}{l}\text { Household, } \\
\text { Government }\end{array}$ & Fluvial & $\begin{array}{l}\text { Empirical } \\
\text { data }\end{array}$ & No & Flood risk & $\begin{array}{l}\text { Local } \\
\text { (Boretto, } \\
\text { ltaly) }\end{array}$ & No \\
\hline $\begin{array}{l}\text { Abebe et al. } \\
(2019)\end{array}$ & $\begin{array}{l}\text { MIKE } \\
\text { FLOOD }\end{array}$ & $\begin{array}{l}\text { Household, } \\
\text { Government }\end{array}$ & Fluvial & $\begin{array}{l}\text { Expert } \\
\text { judgement }\end{array}$ & $\begin{array}{l}\text { Expert } \\
\text { judgement }\end{array}$ & $\begin{array}{l}\text { Flood } \\
\text { damage }\end{array}$ & $\begin{array}{l}\text { Regional (St. } \\
\text { Maarten) }\end{array}$ & No \\
\hline $\begin{array}{l}\text { Coates et al. } \\
\text { (2019) }\end{array}$ & TUFLOW & $\begin{array}{l}\text { Small } \\
\text { Medium } \\
\text { Enterprise, } \\
\text { Insurer, } \\
\text { Government }\end{array}$ & Fluvial & $\begin{array}{l}\text { Empirical } \\
\text { data }\end{array}$ & $\begin{array}{l}\text { Expert } \\
\text { judgement }\end{array}$ & $\begin{array}{l}\text { Production } \\
\text { capacity }\end{array}$ & $\begin{array}{l}\text { Regional } \\
\text { (United } \\
\text { Kingdom) }\end{array}$ & No \\
\hline $\begin{array}{l}\text { Haer et al. } \\
\text { (2019) }\end{array}$ & LisFlood & $\begin{array}{l}\text { Household, } \\
\text { Government, } \\
\text { Insurer }\end{array}$ & Fluvial & $\begin{array}{l}\text { Empirical } \\
\text { data }\end{array}$ & No & Flood risk & $\begin{array}{l}\text { Continental } \\
\text { (European } \\
\text { Union) }\end{array}$ & $\begin{array}{l}\text { Yes / } \\
2100\end{array}$ \\
\hline $\begin{array}{l}\text { Han and } \\
\text { Peng (2019) }\end{array}$ & $\begin{array}{l}\text { SLOSH- } \\
\text { GEV }\end{array}$ & $\begin{array}{l}\text { Household, } \\
\text { Government, } \\
\text { Insurer }\end{array}$ & Costal & $\begin{array}{l}\text { Empirical } \\
\text { data }\end{array}$ & No & Flood risk & $\begin{array}{l}\text { Regional } \\
\text { (Miami Dade, } \\
\text { US) }\end{array}$ & No \\
\hline $\begin{array}{l}\text { Tonn and } \\
\text { Guikema } \\
\text { (2018) }\end{array}$ & $\begin{array}{l}\text { NFIP } \\
\text { maps }\end{array}$ & Household & Fluvial & $\begin{array}{l}\text { Empirical } \\
\text { data }\end{array}$ & No & $\begin{array}{l}\text { Flood } \\
\text { damage }\end{array}$ & $\begin{array}{l}\text { Local (City of } \\
\text { Fargo, } \\
\text { United } \\
\text { States) }\end{array}$ & No \\
\hline $\begin{array}{l}\text { Yang et al. } \\
(2018)\end{array}$ & $\begin{array}{l}\text { Runoff } \\
\text { model }\end{array}$ & Household & Fluvial & $\begin{array}{l}\text { Empirical } \\
\text { data }\end{array}$ & No & $\begin{array}{l}\text { Flood } \\
\text { damage }\end{array}$ & $\begin{array}{l}\text { Regional } \\
\text { (Hong Kong) }\end{array}$ & No \\
\hline $\begin{array}{l}\text { Haer et al. } \\
(2017)\end{array}$ & HIS-SSM & $\begin{array}{l}\text { Household, } \\
\text { Insurer }\end{array}$ & Fluvial & $\begin{array}{l}\text { Empirical } \\
\text { data }\end{array}$ & $\begin{array}{l}\text { Empirical } \\
\text { data }\end{array}$ & Flood risk & $\begin{array}{l}\text { Local } \\
\text { (Rotterdam, } \\
\text { the } \\
\text { Netherlands) }\end{array}$ & $\begin{array}{l}\text { Yes / } \\
2100\end{array}$ \\
\hline $\begin{array}{l}\text { Jenkins et } \\
\text { al. (2017) }\end{array}$ & TUFLOW & $\begin{array}{l}\text { Household, } \\
\text { Insurer, } \\
\text { Government, } \\
\text { Bank }\end{array}$ & Fluvial & $\begin{array}{l}\text { Empirical } \\
\text { data }\end{array}$ & $\begin{array}{l}\text { Expert } \\
\text { judgement }\end{array}$ & Flood risk & $\begin{array}{l}\text { Regional } \\
\text { (London) }\end{array}$ & $\begin{array}{l}\text { Yes / } \\
2050\end{array}$ \\
\hline $\begin{array}{l}\text { Medina et } \\
\text { al. (2016) }\end{array}$ & No & Industrial & Costal & No & No & No & No & No \\
\hline
\end{tabular}


Volume 6 Issue 24 (December 2021) PP. 290-300

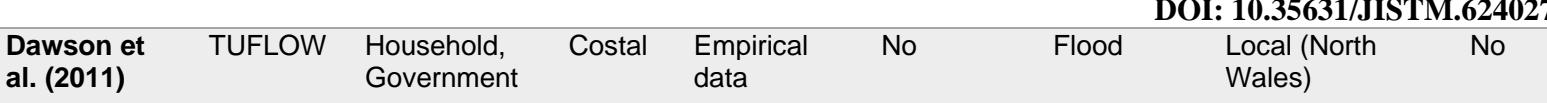

According to Dawson (2011), a research conducted in Towyn, a coastal city in the United Kingdom, shows that the ABM model could analyse flood risks to the people, assist flood contingency plans, and appraise the comfort s of flood event management measures. Basically, the model has been combined with the fluid dynamics model to evaluate the individual likelihood being vulnerable to flood incidents with various storm surge conditions, defences breakthrough scheme, flood warning time and evacuation approaches. For example, Figure 2 shows the average amount of agents affected to a depth of $25 \mathrm{~cm}$ when the defence simulation failed 2173 times and there was no flood warning.

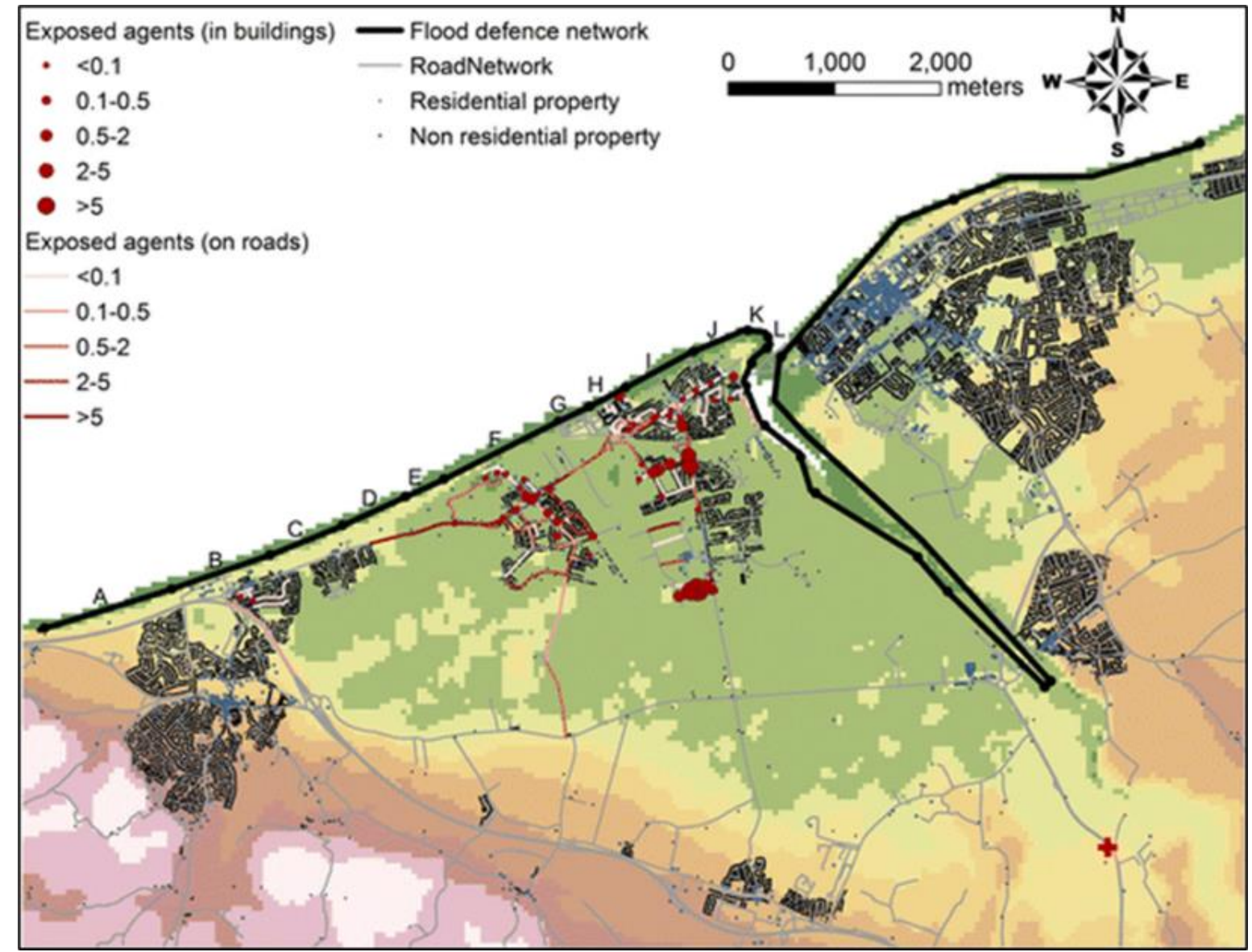

Figure 2: The ABM Model Shows the Number of Exposed Agents to Storm Surges and Failure of Flood Warning

Source: Dawson et al., 2011

According to Abebe (2019), the ABM model have been implemented to simulate the behaviour of participants in urban building development and policies aimed at reducing flood disasters and communities' vulnerability and exposure on St. Maarten in the Caribbean. There were four policies have been considered in the ABM model such as the Beach Policy, Building and Housing Ordinance, Flood Zoning policy and hazard mitigation structural measures. The results show that the structural measures have the highest impact towards the number of exposure houses. 


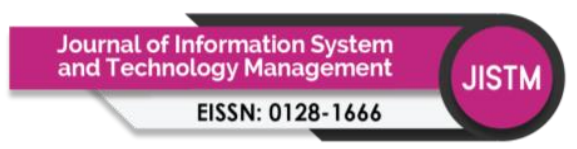

Volume 6 Issue 24 (December 2021) PP. 290-300 DOI: 10.35631/JISTM.624027

In the past, most of previous studies attempt to evaluate the effectiveness of various flood adaptation options in the reduction of flood risk, economic loss, and maximization of evacuation efficiency. However, some researchers indicate that the development of ABM for flood risk assessment faces diverse challenges. For example, the functionality of ABM is limited to simulate a huge complexity and complicated of human-environment system. According to Abebe (2019), the Coupled fLood-Agent-Institution Modelling framework (CLAIM) is conceptualizing and coupled with two complex system such as MAIA (Modelling Agent systems using Institutional Analysis) meta-model and MIKE FLOOD system to simulate the vulnerability of households towards the flood hazard. Generally, ABM platforms still face the limitation of parameter space, especially when modelling large complex systems. For example, complicated abstraction for every phenomenon and constraints in MAIA and MIKE FLOOD cause the CLAIM model to become overly complicated.

In recent years, most of the empirical data used to simulate human behaviour come from an expert judgment or literature not from survey data. Du (2019) described collection of survey data as a specialized and expensive task in the social sciences, and it usually provides data from a point in time for a specific localization case. Thus, the alternative scaling and aggregation methods for data collection have been used especially for the application for larger national and continental scales studies. For instance, the model parameters in Han and Peng (2019) are calibrated according to the existing literature to distinguish individual adaptation behaviours due to lack of personal data. The decision-making of the household or individual on selecting the path between family risk perception and risk mitigation behaviour is differentiated by the empirical data and expert judgment. While according to Yang (2018), the implementation of simplify data such as water flow and household behaviour data have influenced the decisionmaking household during the flood events.

In addition, the implementation of the non-existing phenomena and lacking empirical data or real-time data also challenging the process of the validation and calibration of the ABM model in IFM management (Tonn and Guikema, 2018; Michaelis et al., 2020; Jenkins et al., 2017). Validation is a process of making sure that an implemented model matches the real-world (Helbing, 2012). Many of the assumptions have been made to reduce the complexity of model and represent the real-world data. For example, the agents' behaviour and building data in the Sint Maarten have been simplified and modified due to the limited available dataset (Abebe et al., 2019). In the flood model, the storm surges factor has been classified as the parameter in the flood model while ignoring the wave action and climate change impact factor.

In Abebe (2019), the validation and calibration of ABM model in flood risk also influenced the simplified data on water flow and household behaviour which do not represent the real world. For example, Yang et al. (2018) considered many assumptions to simulate an experimental flood event, such as using only one type of agent (family) to simulate a flood event and did not consider the construction of man-made flood control projects, and the man-made response based on warning information. Thus, the verification and calibration of ABM functions and capabilities in IFM management will be affected (Yang et al., 2018).

Simulating human behaviour and the response to flood events is also one of the challenges faced by the ABM model implemented in flood management. Human responses and decision- 
making data during the flood event are insufficient and incomplete, and it is impossible to parameterize the agent behaviour rules (Jenkins et al., 2017; Medina et al., 2016). According to Haer (2019), it is generally believed that in environmental science, people's behaviour is often ignored by quantitative risk assessment methods. The lack of reliable behavioural data in the designated case area and the limited understanding of quantitative human behaviours together limit the model's reflection of the actual situation and determine it as a pilot simulation. In Yang et al. (2018), the model draws on the general conclusions of some empirical studies to support the exploration of the process of flood loss and various household response measures and compares the effectiveness of different flood response measures.

Besides that, the complexity dynamic of human behaviour also affected the modeler to simulate the individual behave and decision-making during a simulation phenomenon (Sobiech, 2012; Coates et al., 2019). According to Barendrecht et al. (2017) studies, it determines that the output of interactive behaviour is sometimes difficult to understand because the relationship between variables is not as clear as the relationship between system dynamics models on a macro scale. Thus, many of the studies have simplified the human behaviour and response information to simulate complexity of human-environment system (Haer et al., 2017). For example, a rational participant model is usually used in most of the ABM application, which is obviously insufficient to describe the complexity of the human system (Groeneveld et al., 2017). In addition, various decision-making processes may be applied to different agents, or even by the same agent in various situations because humans will not be constrained by an identity or will not follow pre-defined rules to operate.

\section{Conclusion}

In conclusion, the ABM model is a powerful mechanism that can be used by various agencies to develop IFM when communities respond to flood events. Even though the application of $\mathrm{ABM}$ in integrating flood management has shown valuable progress, however, it has limitation due to its capability, functionality and flexibility. Its benefaction to the future flood-related studies specially to evaluate the relationship between human behaviour and decision making towards the flood incidents. In future, the continuous development and improvement of the ABM model approach should be encouraged by enhancing their theoretical foundation, model testing and documentation capabilities. Therefore, in future, the research on the implementation of ABM models in IFM management will be encouraged, especially in simulating the complexity of human behaviour and decision-making during flood events, to reduce the losses caused by the actions and interactions of flood victims (agents) with the local authorities.

\section{Acknowledgement}

We would like to express our gratitude to the Ministry of Higher Education of Malaysia and Universiti Teknologi Malaysia for their financial support in the research grant Vot Number Q.J130000.3852.19J13.

\section{References}

Albano, R., Mancusi, L., \& Abbate, A. (2017). Improving flood risk analysis for effectively supporting the implementation of flood risk management plans: The case study of "Serio" Valley. Environmental Science \& Policy, 75, 158-172. 
Abebe, Y. A., Ghorbani, A., Nikolic, I., Vojinovic, Z., \& Sanchez, A. (2019). A coupled floodagent-institution modelling (CLAIM) framework for urban flood risk management. Environ. Model. Softw., 111, 483-492.

Alghais, N., \& Pullar, D. (2018). Modelling future impacts of urban development in Kuwait with the use of ABM and GIS. Transactions in GIS, 22(1), 20-42.

Bandini, S., Manzoni, S., \& Vizzari, G. (2020). Agent-based modeling and simulation. Complex Social and Behavioral Systems: Game Theory and Agent-Based Models, 667682.

Barendrecht, M. H., Viglione, A., \& Blöschl, G. (2017). A dynamic framework for flood risk. Water Security, 1, 3-11.

Bubeck, P., Kreibich, H., Penning-Rowsell, E. C., Botzen, W. J. W., de Moel, H., \& Klijn, F. (2017). Explaining differences in flood management approaches in Europe and in the USA-a comparative analysis. Journal of Flood Risk Management, 10(4), 436-445.

Castiglione, F. (2020). Agent-Based Modeling and Simulation, Introduction to. Complex Social and Behavioral Systems: Game Theory and Agent-Based Models, 661-665.

Chen, H. H., Stringer, A., Eguale, T., Rao, G. G., \& Ozawa, S. (2019). Impact of antibiotic resistance on treatment of pneumococcal disease in Ethiopia: an agent-based modeling simulation. The American journal of tropical medicine and hygiene, 101(5), 1042.

Chiew, L. S., \& Amerudin, S. (2019). Analysis of burglary crime patterns through the integration of spatial statistics and Agent-Based Modelling. In International Graduate Conference of Built Environtment \& Surveying (pp. 309-318).

Chiew, L. S., \& Amerudin, S. (2020). Applying Agent-based model for teaching and learning in built environment. New Academia Learning Innovation Symposium 2020, 429-437.

Coates, G., Li, C., Ahilan, S., Wright, N., \& Alharbi, M. (2019). Agent-based modeling and simulation to assess flood preparedness and recovery of manufacturing small and medium-sized enterprises. Engineering Applications of Artificial Intelligence, 78, 195217.

CRED-UNISDR. (2015). The Human Cost of Weather-Related Disasters 1995-2015. Centre for Research on the Epidemiology of Disasters (CRED) and United Nations Office for Disaster Risk Reduction (UNISDR).

Dawson, R. J., Peppe, R., \& Wang, M. (2011). An agent-based model for risk-based flood incident management. Natural hazards, 59(1), 167-189.

DeAngelis, D. L., \& Diaz, S. G. (2019). Decision-making in agent-based modeling: A current review and future prospectus. Frontiers in Ecology and Evolution, 6, 237.

Du, E., Rivera, S., Cai, X., Myers, L., Ernest, A., \& Minsker, B. (2017). Impacts of Human Behavioral Heterogeneity on the Benefits of Probabilistic Flood Warnings: An AgentBased Modeling Framework. JAWRA Journal of the American Water Resources Association, 53(2), 316-332.

Fagiolo, G., \& Roventini, A. (2012). Macroeconomic policy in DSGE and agent-based models. Revue de l'OFCE, (5), 67-116.

Fu, G., Meng, F., Rivas Casado, M., \& Kalawsky, R. S. (2020). Towards integrated flood risk and resilience management.

Groeneveld, J., Müller, B., Buchmann, C. M., Dressler, G., Guo, C., Hase, N., \& Schwarz, N. (2017). Theoretical foundations of human decision-making in agent-based land use models-A review. Environmental modelling \& software, 87, 39-48.

Groff, E. R., Johnson, S. D., \& Thornton, A. (2019). State of the art in agent-based modeling of urban crime: an overview. Journal of Quantitative Criminology, 35(1), 155-193. 
Haer, T., Botzen, W. W., \& Aerts, J. C. (2019). Advancing disaster policies by integrating dynamic adaptive behaviour in risk assessments using an agent-based modelling approach. Environmental Research Letters, 14(4), 044022.

Haer, T., Botzen, W. W., de Moel, H., \& Aerts, J. C. (2017). Integrating household risk mitigation behavior in flood risk analysis: An agent-based model approach. Risk Analysis, 37(10), 1977-1992.

Halbe, J., Knüppe, K., Knieper, C., \& Pahl-Wostl, C. (2018). Towards an integrated flood management approach to address trade-offs between ecosystem services: Insights from the Dutch and German Rhine, Hungarian Tisza, and Chinese Yangtze basins. Journal of Hydrology, 559, 984-994.

Han, Y., \& Peng, Z. R. (2019). The integration of local government, residents, and insurance in coastal adaptation: an agent-based modeling approach. Computers, Environment and Urban Systems, 76, 69-79.

Harland, K., \& Heppenstall, A. J. (2012). Using agent-based models for education planning: Is the UK education system agent based?. In Agent-based models of geographical systems (pp. 481-497). Springer, Dordrecht.

Helbing, D. (2012). Agent-based modeling. In Social self-organization (pp. 25-70). Springer, Berlin, Heidelberg.

Heppenstall, A. J., Crooks, A. T., See, L. M., \& Batty, M. (Eds.). (2011). Agent-based models of geographical systems. Springer Science \& Business Media.

Jamali, B., Bach, P. M., \& Deletic, A. (2020). Rainwater harvesting for urban flood management-An integrated modelling framework. Water research, 171, 115372.

Jenkins, K., Surminski, S., Hall, J., \& Crick, F. (2017). Assessing surface water flood risk and management strategies under future climate change: Insights from an Agent-Based Model. Science of the Total Environment, 595, 159-168.

Klijn, F., Kreibich, H., De Moel, H., \& Penning-Rowsell, E. (2015). Adaptive flood risk management planning based on a comprehensive flood risk conceptualisation. Mitigation and Adaptation Strategies for Global Change, 20(6), 845-864.

Macal, C. M. (2020). Agent-based modeling and artificial life. Complex Social and Behavioral Systems: Game Theory and Agent-Based Models, 725-745.

Medina, N., Sanchez, A., \& Vojinovic, Z. (2016). The potential of agent based models for testing city evacuation strategies under a flood event. Procedia engineering, 154, 765772.

Michaelis, T., Brandimarte, L., \& Mazzoleni, M. (2020). Capturing flood-risk dynamics with a coupled agent-based and hydraulic modelling framework. Hydrological Sciences Journal, 65(9), 1458-1473.

Morrison, A., Westbrook, C. J., \& Noble, B. F. (2018). A review of the flood risk management governance and resilience literature. Journal of Flood Risk Management, 11(3), 291304.

Qi, H., Qi, P., \& Altinakar, M. S. (2013). GIS-based spatial Monte Carlo analysis for integrated flood management with two dimensional flood simulation. Water Resources Management, 27(10), 3631-3645.

Qiu, L., Du, Z., Zhu, Q., \& Fan, Y. (2017). An integrated flood management system based on linking environmental models and disaster-related data. Environmental modelling \& software, 91, 111-126.

Railsback, S. F., \& Grimm, V. (2019). Agent-based and individual-based modeling: a practical introduction. Princeton university press. 
Rebaudo, F., Crespo-Pérez, V., Silvain, J. F., \& Dangles, O. (2011). Agent-based modeling of human-induced spread of invasive species in agricultural landscapes: insights from the potato moth in Ecuador. Journal of Artificial Societies and Social Simulation, 14(3), 7.

Rentschler, J., \& Salhab, M. (2020). People in Harm's Way: Flood Exposure and Poverty in 189 Countries. The World Bank.

See, K. L., Nayan, N., \& Rahaman, Z. A. (2017). Flood disaster water supply: a review of issues and challenges in Malaysia. International Journal of Academic Research in Business and Social Sciences, 7(10), 525-532.

Singh, D., Padgham, L., \& Logan, B. (2016). Integrating BDI agents with agent-based simulation platforms. Autonomous Agents and Multi-Agent Systems, 30(6), 1050-1071.

Sobiech, C. (2012). Agent-based simulation of vulnerability dynamics: A case study of the German North Sea Coast. Springer Science \& Business Media.

Suriya, S., \& Mudgal, B. V. (2013). Soft systems methodology and integrated flood management: a study of the A dayar watershed, $\mathrm{C}$ hennai, India. Water and environment journal, 27(4), 462-473.

Tesfatsion, L., Rehmann, C. R., Cardoso, D. S., Jie, Y., \& Gutowski, W. J. (2017). An agentbased platform for the study of watersheds as coupled natural and human systems. Environmental Modelling \& Software, 89, 40-60.

Tonn, G. L., \& Guikema, S. D. (2018). An agent-based model of evolving community flood risk. Risk Analysis, 38(6), 1258-1278.

Turrell, A. (2016). Agent-based models: understanding the economy from the bottom up. Bank of England Quarterly Bulletin, Q4.

Vercruysse, K., Dawson, D. A., Glenis, V., Bertsch, R., Wright, N., \& Kilsby, C. (2019). Developing spatial prioritization criteria for integrated urban flood management based on a source-to-impact flood analysis. Journal of Hydrology, 578, 124038.

Waghwala, R. K., \& Agnihotri, P. G. (2019). Impact assessment of urbanization on flood risk and integrated flood management approach: a case study of Surat city and its surrounding region. ISH Journal of Hydraulic Engineering, 1-11.

Yang, L. E., Scheffran, J., Süsser, D., Dawson, R., \& Chen, Y. D. (2018). Assessment of flood losses with household responses: agent-based simulation in an urban catchment area. Environmental Modeling \& Assessment, 23(4), 369-388. 